Authors have nothing to disclose with regard to commercial support.

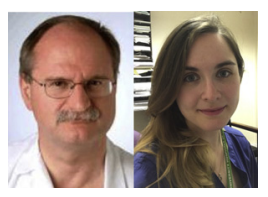

\section{POTENTIAL USEFULNESS OF N-TERMINAL PRO- BRAIN NATRIURETIC PEPTIDE LEVEL IN CONGENITAL HEART SURGERY}

\section{To the Editor:}

In a recent article, $\mathrm{Qu}$ and colleagues ${ }^{1}$ reported their observations on the relationship between N-terminal pro-brain natriuretic peptide (NT-proBNP) levels at different time points and early outcome in an attempt to evaluate the reliability of NT-proBNP level as a predictor of early outcome after congenital heart surgery. It would certainly be useful to have such a tool available in the perioperative management of children with congenital heart defects undergoing surgery, but there is probably space for improvement in the proposed methodology.

$\mathrm{Qu}$ and colleagues ${ }^{1}$ failed to define some of the exclusion criteria, such as renal dysfunction, for which no laboratory results or cutoff points were specified. This point is quite important, considering the relatively high incidence of renal dysfunction in children with congenital heart defects. ${ }^{2}$ Because NT-proBNP is produced by other cells in the body for various reasons (renal dysfunction being among them), confounding factors in its measurement should be avoided whenever possible.

Other undefined information included details of inotropic support, which was limited to the duration but without data on the vasoactive inotropic score, which would give more accurate information about the relationships between patient's condition and the corresponding NT-proBNP levels.

No objective assessment of the ventricular function was provided, only the Risk Adjustment in Congenital Heart Surgery 1 score, with $75 \%$ of children scored as I or II, $25 \%$ as III or IV, and none as V or VI. Not only was the more precise Aristotle Comprehensive Complexity score not used, even if this point had been included in the limits of the study, all patients at high risk were still excluded.

The Editor welcomes submissions for possible publication in the Letters to the Editor section that consist of commentary on an article published in the Journal or other relevant issues. Authors should: • Include no more than 500 words of text, three authors, and five references. • Type with double-spacing. • See http://jtcs.ctsnetjournals.org/ misc/ifora.shtml for detailed submission instructions. • Submit the letter electronically via jtcvs.editorialmanager.com. Letters commenting on an article published in the JTCVS will be considered if they are received within 6 weeks of the time the article was published. Authors of the article being commented on will be given an opportunity of offer a timely response ( 2 weeks) to the letter. Authors of letters will be notified that the letter has been received. Unpublished letters cannot be returned.
The results were expressed as percentages, without indicating the full numbers that would probably have better illustrated the interpatient variability in NT-proBNP levels and whether they were relevant.

Finally, Qu and colleagues ${ }^{1}$ concluded that NT-proBNP value could be correlated with prognostic information on expected outcomes, even though further studies will be required establish the statistical significance. How can this conclusion provide inferences for the application of this value in daily clinical practice? Ultimately, knowing the NT-proBNP levels could have a potential utility only if it could be used to modify the treatment of the patients, which was not demonstrated by $\mathrm{Qu}$ and colleagues. ${ }^{1}$

In summary, it was extremely important to present this specific biomarker as a potential tool in the post-operative management of congenital cardiac patients. To validate the clinically utility of NT-proBNP level, however, further investigations into its prognostic ability are required in a larger, more heterogeneous patient population.

Alexandra Monaghan, $M B C h B, B S c^{c}$ Antonio F. Corno, MD, FRCS, FETCS, FACC ${ }^{a, b}$ ${ }^{a}$ Pediatric and Congenital Cardiac Surgery East Midlands Congenital Heart Center Glenfield Hospital

University Hospitals of Leicester Leicester, United Kingdom

${ }^{b}$ Cardiovascular Research Centre University of Leicester Leicester, United Kingdom

\section{References}

1. Qu J, Liang H, Zhou N, Li L, Wang Y, Li J, et al. Perioperative NT-proBNP level: potential prognostic markers in children undergoing congenital heart disease surgery. J Thorac Cardiovasc Surg. 2017;154:631-40.

2. Jacobs JP, O’Brien SM, Pasquali SK, Kim S, Gaynor JW, Tchervenkov CI, et al. The importance of patient-specific preoperative factors: an analysis of the Society of Thoracic Surgeons congenital heart surgery database. Ann Thorac Surg. 2014;98:1653-8.

3. Boian M, Gerelli S, Gioanni S, Pouard P, Vouhé P. Comparative study of the Aristotle Comprehensive Complexity and the Risk Adjustment in Congenital Heart Surgery scores. Ann Thorac Surg. 2011;92:949-56.

\section{https://doi.org/10.1016/j.jtcvs.2018.01.037}

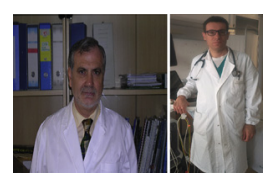

THE PROGNOSTIC

ROLE OF

NATRIURETIC

PEPTIDES IN

CHILDREN

UNDERGOING

CARDIAC SURGERY:

CAN ACUTE KIDNEY INJURY AFFECT

THEIR ACCURACY?

Reply to the Editor:

Recent evidence supports the use of brain natriuretic peptide (BNP) and N-terminal pro-BNP as prognostic 